\title{
The Role of Problem Solving Approach in Building Students' Self Confidence on Learning Mathematics
}

\author{
Kunny Kunhertanti, \\ Post Graduate of Mathematics Education \\ Yogyakarta State University \\ Indonesia \\ kunny.kunhertanti@gmail.com
}

\author{
Rusgianto Heri Santosa \\ Post Graduate of Mathematics Education \\ Yogyakarta State University \\ Indonesia \\ santosa_rh@yahoo.co.id
}

\begin{abstract}
Mathematics learning succes is influenced by many factors. One of the factors is students' self-confidence. High selfconfidence influences students to learn mathematics better. This is because the aspects contained in the students' self-confidence are beliefs in self-ability to mathematics, optimistic attitudes, objectives, responsible, rational and realistic thinking. Aspects on students' self-confidence need to be developed. One way is using problem-solving approach. The use of Problem-solving approach focuses on students in facing mathematics problems during their learning. With this approach, students are trained in rational and realistic thinking, particularly life-related issues. The positive side of using problem-solving approach is that students feel satisfied and proud of their work in solving problems. It gives a positive impact on students' improvement in learning mathematics. This study was conducted on a group of junior high school students, aiming to know the positive impact of problem-solving approach in building students' self-confidence in learning mathematics. The data analysis to test the difference of initial condition and after treatment used one way anova. Based on the Anova table, it was gained sig score $=.000<.05$, meaning there was different increased score between the experimental class and the control class. By sefering to the empirical average in the descriptive table, it is seen that the average score of experimental class $=.4110>$ the average score of the control class $=\mathbf{. 0 1 5 5}$. thus, it can be concluded the self confidence among students who used problem solving approach was better than the class who didn't get the treatment
\end{abstract}

Keywords-mathematics learning, problem solving approach, self-confidence

\section{INTRODUCTION}

The learning objectives in various countries include the Singapore's Mathematics Framework (SMF), the National Council of Teachers of Mathematics (NCTM), and even the Regulation of the Minister of National Education (Permendiknas) in Indonesia. There are some issues of concern, for example problem solving, reasoning and proof, communication, connection, and representation. Matters of concern have the intention for students to understand mathematics well and gain achieve in mathematics. Piper and Lincoln states that if students start to develop an understanding of mathematical concepts, their attitudes about mathematics, confidence in mathematical understanding so that after that their achievements are expected to increase [1]. This explains that self-confidence has an important role in improving mathematics learning achievement. In line with that opinion in the objective of mathematics learning in Permendiknas, NCTM mentioned that mathematics learning achievement is influenced by various factors in which one of them is self-confidence of students in learning mathematics [2], [3].

Permendikbud no 58 year 2014 states that in learning mathematics students are expected to have an appreciation of the usefulness of mathematics in life, which has a curiosity, attention, and interest in learning mathematics, and resilient attitude and confidence in solving major problems in everyday life. Moreover, in NCTM also explains that problem solving includes confidence and willingness to solve new problems or difficult problems [3]. While in SMF there are aspects of attitudes which also emphasize the students' self-confidence. On the basis of these things can be seen that self-confidence is an important aspect that affects the achievement of learning mathematics.

Reference [4] states that confidence is a faith or belief in one's self and one's own abilities to succeed. It is the belief that one will act in a right, proper, or effective manner. Furthermore Willis (in Gufron and Risnawita, S.) states that self-confidence is the belief that a person is able to tackle a problem with the best situation and can provide something pleasing to others [5]. Self-confidence is a positive mental attitude of an individual who positioned or conditioned himself can evaluate about themselves and their environment so that it feels comfortable to perform activities in an effort to achieve the planned goals [6]. Furthermore, Reddy self confidence is an attidue which allows individuals to have positive yet realistic views of themselves and their situations. Self-confidence of people trust their own abilities, have a general sense of control in their lives, and believe that, within reason, they will be able to do what they wish, plan, and expect [7]. Self-confidence refering to Lie is convinced of her ability to complete a job and a problem [8]. Furthermore, the confidence according to Salirawati is defined as a confidence in the ability of self against the fulfillment of every desire desires and expectations [9]. Self-confidence (usually termed just confidence) refers to self-belief about abilities to do and learn mathematics in some context, not 
necessarily generally. Hence a learner may be confident within one area of mathematics, but else not another [10]. Based on the study above, it can be concluded that self-confidence (confidence) is a belief in the ability of a person, whether in terms of planning activities and tackle (overcome) problems. In addition, self-confidence is a positive attitude in a person and can always give the impact of comfort for others.

Five aspects that build self-confidence, namely: selfawareness, intention, thinking, imagination, and acting as if [11]. However, according to Lauster (in MN Ghufron \& Rini Risnawati S.) convey aspects of self-confidence are: (a) belief in self-ability, (b) optimistic, (c) objective, (d) rational and reality[9].

The importance of self confidence in mathematics learning is not followed on an international scale, only $14 \%$ of students have high self-confidence related to their mathematical ability. While $45 \%$ of students included in the category of moderate, and the remaining $41 \%$ including low category. This is similar to what happens to students in Indonesia, ie $3 \%$ of students who have high self confidence in learning mathematics, while $52 \%$ included in the category of moderate and $45 \%$ included in the low category. It shows that the effort in increasing selfconfidence of students is still in need in learning mathematics [3].

Seeing the importance of efforts made in improving student self confidence in mathematics learning, the teacher can choose a learning approach that accommodates the development of self-confidence students. Adhetia Martyanti states that the use of problem solving approach can improve student self confidence in learning mathematics [12]. Taplin argues that the problem-solving approach is an approach that encourages flexibility, the ability to respond to unexpected situations that do not have immediate solutions, and helps to develop perseverance in the face of failure [13]. The problem-solving approach can be useful for students to build their own ideas about mathematics and take responsibility for learning. There are positive things that students get when both solving problems and after successfully solving the problem. When solving problems, students gain the opportunity to develop realistic and rational thinking skills. While the other positive things obtained when students successfully solve the problem is the emergence of a sense of satisfaction and pleasure in students. This will contribute to students 'positive attitudes towards mathematics and will add students' confidence in mathematics learning [14]. Furthermore, the problem-solving learning approach is a process in which learners practice combining previously learned knowledge, rules, techniques, skills and concepts to find a solution to an undiscovered problem [15]. In a study conducted by Guler \& Ciltas states that the purpose of the

sampling is random from all seventh-grade students, using the lottery. The first class was experimental group with given treatment that was problem solving approach while group of control class used approach which usually done by teacher. Experiment class consist of 30 students and the control class consist of 27 students. problem-solving approach is to enable students to think in an advanced way [16]. Lester \& Schroeder state the problem solving approach is real-life and simulated problem situations provide context and reason for learning mathematics[17].

In addition Schroede \& Lester illustrates three principles of approach to problem solving learning: 1) learning about problem solving; 2) teaching to solve problems; 3) learning through problem solving [17]. Other notions on steps to teach problem solving: a) identifying problems in the book, b) Determining problem solving, c) identifying problem-solving constraints, d) reviewing resolutions and select one, e) determining the settlement by trying out the selected settlement, and f) evaluating how the settlement is done [18]. Furthermore the steps of problem solving are: 1) identifying the objectives to be achieved, 2) describing obstacles or obstacles that hamper the achievement of the objectives of problem solving; 3 ) identifying different solutions to overcome obstacles or constraints and hypotheses which solutions are possible and most effective, 4) attempting solutions in reality or through simulation, and 5) explaining whether the hypothesis is correct and determining whether it intends to test other hypotheses using different solutions [19]. The general form of problem solving from Bransford \& Stein is divided into five parts of the process, called "IDEAL problem solver", ie: 1) identifying problems, 2) defining and describing problems, 3) investigating possible strategies, 4) act to resolve with various strategies, and 5) review results and evaluate [20].

From the steps described above, it can be concluded that the problem-solving approach has the following steps: 1) identifying the problem, 2) defining the problem, 3) planning the settlement, 4) executing the plan, and 5) evaluating the results

\section{RESEARCH Methodology}

Research method used in this research is quasi experiment research. This is because the selection of experimental groups cannot be done randomly. Meanwhile, the research design used is pre-test post-test nonequivalent compare group design.

In this research will be done pretest and post-test design. This pre-test aims to determine the initial condition of students related to self-confidence of students before any treatment. Meanwhile, the post-test aims to determine the effectiveness of learning problem solving approach in the experimental class and the learning in the control class, after being compared with the pre-test.

This research was conducted in one of junior high school (SMP) in downtown Yogyakarta in September until November 2017. The population is all students in grade VII in academic year 2017/2018 which consists of 7 classes. Classroom

Independent variable in this research is problem solving approach and one dependent variable is self-confidence of student. Data collection techniques used in the research in the form of questionnaire about students' self-confidence, both before learning and after learning on a sample that has been determined. Data collection techniques were conducted by first giving a pre-test question of students' self-confidence before 
the treatment of the specified samples. After that, the research began to be implemented using the learning that has been described above. The application of the problem-solving approach to the experimental class and untreated class. After that it ended with the questionnaire of self-confidence of students after giving treatment to two classes as the sample.

In this research, data analysis technique is done by describing data and analyzing inferential statistics to the data obtained. After the sample groups were treated, a test of the hypothesis was proposed. Firstly, the data obtained by testing the normality of data distribution with the formula chi square. Furthermore, testing the homogeneity of variance with Levene test, and hypothesis testing is done by One Way Anova test with $5 \%$ significance level

\section{RESUlT AND DiSCUSSION}

Instrument in this research is non-test instrument, which is questionnaire about students' self-confidence. The questionnaire used consisted of 30 items of statement outlined from five predetermined aspects and used a Likert-scale measurement

Based on the data obtained through self-confidence questionnaire of students given to the experimental class and control class at the school, then next will be analyzed data as follows

\section{Normality Test}

The normality test is performed to determine whether the sample data is from a normally distributed population. The test was performed using the Mahalanobis distance test $\left(d_{i}{ }^{2}\right)$. The compliance of the multivariate normality is by using the criterion $\chi^{2}$ ie if about $50 \%$ of data have value $d_{i}{ }^{2}<\chi_{(p ; 0,5)}^{2}$ (distance - squares are smaller and chi-square) then it can be said the data is normally distributed [21]. Multivariate normality test is done using the help of Microsoft Office Excel program with 2016 version

TABLE I. SUMMARY OF SELF CONFIDENCE STUDENT DATA ANALYSIS IN MATHEMATICS LEARNING

\begin{tabular}{|c|c|c|c|c|}
\hline \multirow[t]{2}{*}{ Variabel } & \multicolumn{2}{|c|}{ Experimental Class } & \multicolumn{2}{|c|}{ Control Class } \\
\hline & Pre Questionnaire & Post Questionnaire & Pre Questionnaire & Post Questionnaire \\
\hline $\mathrm{N}$ & 30 & 30 & 27 & 27 \\
\hline$\overline{\bar{Y}}$ & 92.3 & 117.6333 & 91.03704 & 92.81481 \\
\hline SD & 13.28507 & 14.28885 & 6.247963 & 5.717968 \\
\hline $\begin{array}{c}\text { Persentase } \boldsymbol{d}_{\boldsymbol{i}}{ }^{2}< \\
\chi_{(\boldsymbol{p} ; \mathbf{0}, \mathbf{5})}^{2}\end{array}$ & $80.00 \%$ & $66.67 \%$ & $74.07 \%$ & $74.07 \%$ \\
\hline
\end{tabular}

From the table it is found that the data from the prequestionnaire and the post-questionnaire either in the experimental class or control class is normal.

\section{Homogenity Test}

Homogeneity test aims to find out whether the data in the experimental group has the same or not the covariance variance matrix. To know the homogeneity of covariance matrix was done by using Levene test by using SPSS program. The decision criteria in multivariate homogeneity test at $5 \%$ significance level are as follows:

$\boldsymbol{H}_{\mathbf{0}}$ : data is a homogen

$\boldsymbol{H}_{1}$ : data is heterogen

The criterion: Reject $\boldsymbol{H}_{\mathbf{0}}$ if the value of significance $<.05$

TABLE II. TABLE RESUlt OF HOMOGENEITY TEST

\begin{tabular}{|c|c|c|c|}
\hline \multicolumn{4}{|c|}{ Test of Homogeneity of Variances } \\
\hline Gain_score & & & \\
\hline Levene Statistic & df1 & $\mathrm{df} 2$ & Sig. \\
\hline 3,927 & 1 & 55 &, 053 \\
\hline
\end{tabular}

Based on the table, it can be seen that the significance value is .053> .05 thus $H_{0}$ is accepted. So the data at the homogeneous gain value.

\section{One Way ANOVA Test}

One-way ANOVA test is used to see whether there is an increase in value between the experimental class and the control class.

$$
\begin{aligned}
& \boldsymbol{H}_{0}: \boldsymbol{\mu}_{1}=\boldsymbol{\mu}_{2}, \quad \begin{array}{l}
\text { meaning there is no difference in the } \\
\text { value increase between the } \\
\text { experimental class and the control class }
\end{array} \\
& \boldsymbol{H}_{1}: \boldsymbol{\mu}_{1} \neq \boldsymbol{\mu}_{2}, \begin{array}{l}
\text { meaning there is a difference in value } \\
\text { increase between the experimental class } \\
\text { and the control class }
\end{array}
\end{aligned}
$$

The criterion: Reject $\boldsymbol{H}_{\mathbf{0}}$ if significance value $<.05$

As for, the decision criteria in the One Way ANOVA test is rejected $\mathrm{H}_{0}$ if the significance value $<.05$. 
TABLE III. TABLE ANOVA

\begin{tabular}{|c|r|r|r|r|r|}
\hline \multicolumn{7}{|c|}{ ANOVA } \\
\hline Gain_score & $\begin{array}{c}\text { Sum of } \\
\text { Squares }\end{array}$ & df & Mean Square & F & \multicolumn{1}{c|}{ Sig. } \\
\hline & 2,223 & 1 & 2,223 & 42,817 &, 000 \\
\hline Between Groups & 2,856 & 55 &, 052 & & \\
\hline Within Groups & 5,080 & 56 & & & \\
\hline Total & & & & &
\end{tabular}

Based on the ANOVA table it is obtained sig $=$ value $<.05$, thus $H_{0}$ is rejected and $H_{1}$ accepted. So it means there is a difference in value increase between the experimental class and the control class.

TABLE IV. TABLE DESCRIPTIVES

\begin{tabular}{|c|c|c|c|c|c|c|c|c|}
\hline & \multirow[b]{2}{*}{$\mathrm{N}$} & \multirow[b]{2}{*}{ Mean } & \multirow[b]{2}{*}{$\begin{array}{c}\text { Std. } \\
\text { Deviation }\end{array}$} & \multirow[b]{2}{*}{$\begin{array}{l}\text { Std. } \\
\text { Error }\end{array}$} & \multicolumn{2}{|c|}{$\begin{array}{l}\text { 95\% Confidence Interval for } \\
\text { Mean }\end{array}$} & \multirow[b]{2}{*}{ Minimum } & \multirow[b]{2}{*}{ Maximum } \\
\hline & & & & & $\begin{array}{l}\text { Lower } \\
\text { Bound }\end{array}$ & Upper Bound & & \\
\hline $\begin{array}{l}\text { Experimental } \\
\text { Class }\end{array}$ & 30 &, 4110 & ,26792 & ,04892 & ,3110 & ,5111 &,- 24 & ,94 \\
\hline Control Class & 27 &, 0155 & ,17258 & ,03321 &,- 0528 &, 0838 &,- 33 &, 25 \\
\hline Total & 57 & ,2237 & 30118 & ,03989 &, 1438 & ,3036 &,- 33 & ,94 \\
\hline
\end{tabular}

By looking at the empirical averages in the descriptive table IV, it appears that the average gain score of the experimental class $=.4110>$ the average gain score of the control class $=$ .0155. so it can be concluded that self confidence in the class that uses problem solving approach is better than the class that did not get treatment

\section{CONCLUSION AND RECOMMENDATION}

Based on the results of hypothesis testing and discussion can be concluded that self confidence in learning mathematics with problem solving approach has a better result compared with conventional mathematics learning.

Given that self-confidence is one aspect that plays a role in improving student achievement in learning mathematics, then this can be used by teachers to improve self-confidence students in learning mathematics

\section{REFERENCES}

[1] Piper, B.D, "Attidues, cofindence, and achievement of high-ability fifth grade math students," Summative Projects for MA Degree. Lincoln: University of Nebraska. Paper 29, 145, 2008

[2] Depdiknas, Permendiknas Nomor 22 Tahun 2006 Tentang Standar Isi Sekolah Menengah Pertama. Jakarta: Depdiknas, 2006.

[3] National Council of Teachers of Mathematics, Principles and standars for school mathematics. Reston, VA: Author, 2000.

[4] McElmeel, S. L, "Character Education: A book guide for teachers, librarians, and parents," Greenwood Village: Greenwood Publishing Group.Inc, 2002.

[5] Gufron, M.N. and Risnawita S., R, “Teori-teori psikologi,” Yogyakarta: Ar-Ruzz Media, 2012

[6] Huri Suhendri, "Pengaruh kecerdasan matematis-logis, rasa percaya diri, dan kemandirian belajar terhadap hasil belajar matematika," Prosising Seminar Nasional Matematika dan Pendidikan Matematika UNY 10 November 2012, 2012.

[7] Reddy, M.M, "A study of self-confidence in relationto achievement motivation of D.ed student," Global Journal for Research Analysis. Vol. 3, ISSN No. 2277, pp. 56-58, 2014.
[8] Lie, A. "101 Cara menumbuhkan percaya diri anak," Jakarta: PT Elex Media Komputindo, 2003

[9] Salirawati, D, "Percaya diri, keingintahuan, dan berjiwa wirausaha: Tiga karakter penting begi peserta didik," Jurnal Pendidikan Karakter, Tahun II, No. 2, pp. 213-224, 2012

[10] Cretchley, P.D, "Advancing Research Into Affective in Mathematics Learning: Clarifying Key Factors, Terminology and Measurement," Proceding of the 31rd Annual Conference of the Mathematics Education Research Group of Australasia, pp. 147-153, 2008

[11] Preston, D.L, “365 Steps to self-confidence," Oxford: How To Content, 2007.

[12] Adhetia Martyanti, "Membangun self-confidence siswa dalam pembelajaran matematika dengan pendekatan problem solving," Prosiding, Seminar Nasional Matematika dan Pendidikan Matematika yang diselenggarakan oleh FMIPA UNY, tanggal 9 November 2013 Yogyakarta: Universitas Negeri Yogyakarta, 2013.

[13] Taplin, M, "Mathematics through Problem Solving. Mental math," Diambil pada tanggal 7 September 2017 dari http://www.mathgoodies.com/articles/problem_solving.html, 2010

[14] Haylock, D., and Thangata, F, "Key concepts in teaching primary mathematics," London: Sage Publications, 2007.

[15] Orton, A, "Learning Mathematics: Issue, theory and classroom practice ( $3^{\text {rd }}$ es)," London. New York: Continuum, 2004.

[16] Guler, G. and Ciltas, A, "The visual representation usage levels of mathematics teachers and students in solving verbal problem," International Junal of Humanities and Social Science, vol 1 nomor 11, pp.145-154, 2011.

[17] Kennedy, L. M., Tipps, S., and Johnson, A, "Guiding children's learning of mathematics (11th ed)," Belmont, California: Thomson Wadswort, 2008.

[18] Forgan, J.W, “Teaching problem solving through children's literature" Wesport, MA: Greenwood publishing group, 2003.

[19] Marzano, et al, "A Handbook for Classroom Instruction that Works," United States:Library of Congres Cataloging-in-Publication Data, 2001.

[20] Nitko, A. J. and Brookhart, S.M, "Educational Assessment of Students," Boston, MA: Person Education, 2011.

[21] Johnson, R. A., and Winchern, D. W, "Applied multivariate statistical analysis $\left(6^{\text {th }}\right.$ ed)," New York: Pearson Prentice Hall, 2007. 